\title{
NUMERICAL STUDY OF HEAT TRANSFER DURING NUCLEATE POOL BOILING
}

\author{
Andrijana Stojanović ${ }^{\star *}$, Vladimir Stevanović ${ }^{2}$ Milan Petrović ${ }^{2}$, Dragoljub Živković ${ }^{3}$, \\ Branislav Stanković ${ }^{1}$

\footnotetext{
1 University of Belgrade, Institute of Nuclear Sciences Vinca, Laboratory for Thermal Energy and Engineering, 11000 Belgrade, Serbia

3 Faculty of Mechanical Engineering, University of Niš, 18000 Niš, Serbia
} \\ 2 Faculty of Mechanical Engineering, University of Belgrade, 11000 Belgrade, Serbia
}

In this paper three-dimensional numerical simulation of the atmospheric saturated pool boiling was performed. The applied modelling and numerical methods enable full representation of the two-phase mixture behaviour on the heating surface with the inclusion of the swell level prediction. The three-dimensional investigation presented here was performed in order to take into account a convective heat transfer on the heated surface, as well as spatial effects of the vapour generation and a twophase flow such as phase dispersion within the two-phase mixture. The results are presented for a short period of time after the initiation of the heat supply and vapor generation on the heating surface. The replenishment of the heating surface with water and partial surface wetting for lower heat fluxes is shown. The influence of the density of nucleation sites and the bubble residence time on the wall on the pool boiling dynamics is discussed. Also, the influence of the heat flux intensity on the pool boiling dynamics is investigated. The applied numerical and modelling method showed robustness by allowing stable calculations for wide ranges of applied modelling boiling parameters.

Introduction

Boiling heat transfer has always been a very interesting research field because of the high efficiency of this process in removing the heat from a solid body using liquids. Several studies [1,2,3] focussed on the understanding of the fluid-solid combinations in order to obtain the highest heat fluxes at the minimum wall superheat. High values of this parameter could lead to possible alteration of thermal heat transfer characteristics of the solid substrate. However, despite the fact that research has been carried on for several decades, the complete picture of the processes involved is far from complete, partly due to the nonuniformity of the conditions and characteristics of the materials during the experiments (substrates and liquids, as well as measuring instrumentation), to the non-linearity of the processes and to the possible presence of hysteresis phenomena (generally related to the activation temperature for a nucleation site significantly higher than the expected or theoretical value). Due to the complexity of the research area, the studies focus on different aspects, from the formulation of predictive correlations to dedicated experiments investigating specific aspects or to the analysis of the results of complex numerical simulations.

Modelling boiling requires many hypotheses the validity of which can not always be assessed. This results in a large number of different models, often with corrective factors. The results predicted by these models are sometimes far from the experimental results. The experiments in boiling also receive their share of difficulties. Phenomena are fast, bubbles interact, scales are multiple, material properties are not always well defined, especially the wall roughness, and physical parameters are hard to measure in fluids. Boiling needs to be simplified in order to identify the role of different mechanisms involved. Many of the early models [4] were based on bubble agitation-microconvection being the primary heat transfer mechanism. These models did not include the phase change, but relied on an analogy with forced convection i.e. the role of the bubble was to change the length and velocity scales used to correlate data (e.g., Rosenhow 1952; Forster and Zuber, 1955; Forster and Greif 1959; Zuber 1963; Tien 1962). For example, the vapor-liquid exchange model proposed by Forster and Greif [5] assumed that bubbles act as micropumps that remove a quantity of the hot liquid from the wall equal to the hemisphere at the maximum bubble radius, replacing it with the cold liquid from the bulk. The heat transferred from a single site was the energy required to heat this volume of the liquid from the bulk temperature to the average of the wall and bulk temperatures.

\footnotetext{
*Author address: Andrijana Stojanović, University of Belgrade, Institute of Nuclear Sciences Vinca, Laboratory for Thermal Energy and Engineering, 11000 Belgrade, Serbia

E-mail: andrijana@vin.bg.ac.rs

The manuscript received: March, 17, 2016.

Paper accepted: June, 06, 2016.
} 
In this study, the numerical simulations with two different values of the heat flux, bubble nucleation sites density and bubble residence time were performed, showing the influence of these parameters on the pool boiling dynamics. The pool boiling is considered and heat is supplied through the bottom wall. Spatial and temporal sites and intensities of the vapor generation are prescribed on the heated surface as boundary conditions, while the vapor volume exists above the two-phase mixture swell level. The heated wall is divided into zones, while within each zone the spatial and temporal random generation of the vapour on the heated wall is introduced. In this way, the microscopic conditions of the vapour generation at the nucleation sites within the liquid micro-layer on the heated wall are included, and the chaotic and complex dynamics of the micro scale small vapour bubbles generation, rise and departure at the heater are considered as a very important boundary condition for the CFD investigations of the macroscopic pool boiling. Bulk boiling conditions are modelled with the two-fluid model. Mass, momentum and energy balance equations are written for vapour and the liquid phase, while necessary closure laws are stated for interface transfer processes. Special attention is given to the formulation of the appropriate closure law for the interfacial drag momentum transfer due to the shear stress, because of its significant influence on the two-phase flow modelling accuracy.

Boundary and Initial Conditions for Numerical Simulations

Pool boiling is simulated in a square vessel, initially filled with the saturated stagnant water up to $0.02 \mathrm{~m}$, Figure1. The vessel is open to the atmosphere. The water level corresponds to the collapsed two-phase mixture level of the BETA physical experiments presented in [68]. The bottom wall heating starts at $0.1 \mathrm{~s}$ after the initial time, and the calculation during this period is performed in order to establish a proper pressure field within the vessel. Vapor bubbles are generated at the bottom wall. The wall is heated uniformly at the bottom surface.

At the initial state, the collapsed and swell level coincide, while later on, during the vapor generation, the swell level dynamically moves, and its position is predicted with the here presented numerical approach. It was found that the inclusion of the swell level, as the upper boundary for the liquid flow domain is necessary in order to reliably predict the water recirculation in the pool boiling. The volume above the swell level, up to the vessel exit is filled with vapour, Figure 1. The vapour exit part in the vessel is modelled with a higher hydraulic resistance in order to stabilize the outlet vapor stream. There is no water feeding during boiling, which leads to the constant water depletion due to the evaporation. For the evaporation of the total water mass within the vessel under the heat flux of $1500 \mathrm{~kW} / \mathrm{m}^{2}$, a period of approximately $27 \mathrm{~s}$ is needed. Hence, the depletion of the water mass is of no influence on here presented computational results, since numerical simulations are performed for time periods within a few seconds from the initial state.
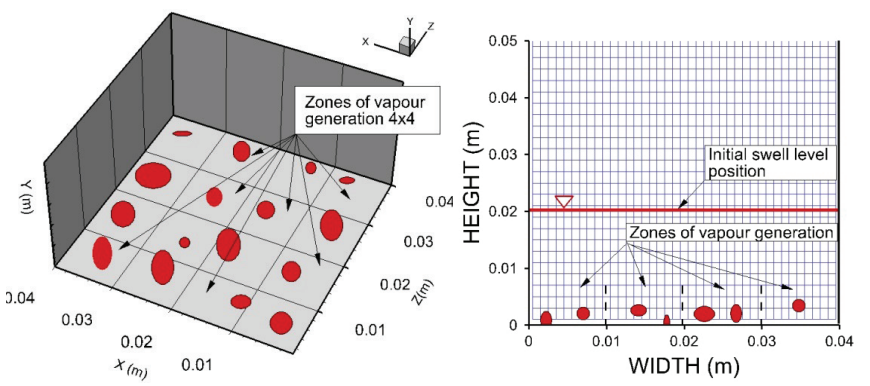

Figure1. Numerical grid with $40 \times 50 \times 40$ (width $\times$ height $\times$ depth) control volumes for pool boiling simulation

Micro-scale Parameters in Model of Boiling Dynamics Micro-scale model of the bubble growth applied here is developed and presented in $[9,10]$. The water capillarity length is used for scaling the infinite geometry and it is defined with:

$$
L_{c}=\sqrt{\frac{\sigma}{g\left(\rho_{1}-\rho_{2}\right)}}
$$

and for atmospheric conditions it is equal to $2.5 \cdot 10^{-3} \mathrm{~m}$. The applied vessel dimensions are several times greater than the capillary length.

The density of nucleation sites and corresponding width of the zone for random bubble generation are input parameters for here presented simulations. The nucleation site density is determined with the heat flux, heating surface roughness, a wetting contact angle and thermophysical characteristics of the boiling fluid and the wall. The relation between the density of nucleation sites $n$ and the zone width $b$ can be derived from the simple geometric condition that one square meter is covered with $n$ nucleation sites, i. e.

$$
b=\frac{1}{\sqrt{n}}
$$
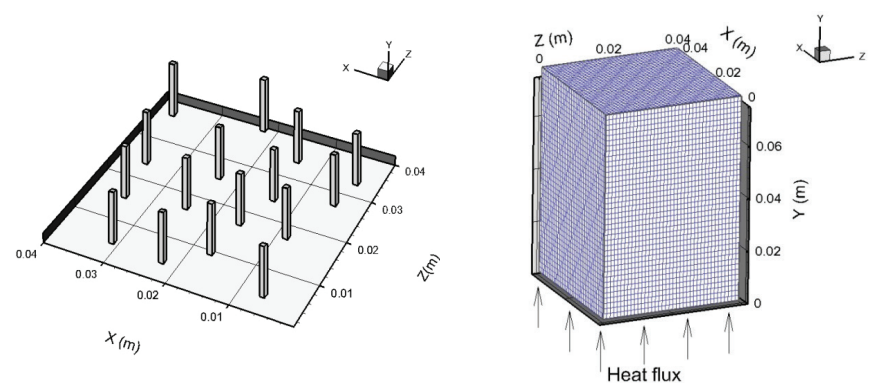

Figure 2. Heat flux at random discrete locations within bubble generation zones (left) and numerical grid (right)

The vapor generation at the randomly chosen location (nucleation site) is determined by the bubble residence time on the heating wall. It is also assumed that the major portion of the heat is transferred at the nucleation site, and the sensible heat is neglected in regard to the latent heat of evaporation, Figure 2. The two main parameters 
of the boiling algorithm are the width of the zone and the bubble residence time on the heating wall. As it is shown by the obtained results, these modelling parameters determine the dynamics of the calculated pool boiling. Also, these parameters are closely determined with the physically based characteristics of the boiling process.

The roughness of the fresh surfaces is smaller, with a lower number of recesses; hence, boiling at the fresh surface is characterized with a lower nucleation site density. Also, the wetting contact angle is increased on fresh heaters [7]. The influence of the surface roughness and condition (fresh or aged) is introduced in the present discussion through the contact angle $\theta$. A theoretical model of the bubble growth on the heating surface led to the following correlation for the bubble diameter at the moment of separation from the wall [9].

$D_{b}=0.0208 \times \theta \times L_{c}$

where the contact angle $\theta$ is measured in degrees. The equation (4) was assessed in [11] and its good prediction ability is confirmed by comparing with experimental results. No dependence of the bubble departure diameter on the heat flux is shown by Eq. (4). The weak relation between the heat flux and the diameter of the bubble at detachment is also confirmed in [12]. For a heavily aged surface the contact angle of $5 \mathrm{deg}$. could be assumed, and for atmospheric conditions the bubble departure diameter of $2.6 \cdot 10^{-4}$ is calculated with Eq. (4). For higher heat fluxes, and especially for the conditions close to the departure from nucleate boiling it can be assumed that the whole heating surface is covered with bubbles, which is described with a simple geometric relation that one square meter is covered with $n$ bubbles of diameter $D_{b}$, as follows,

$n D_{b}^{2}=1$

where $n$ is the density of nucleation sites. For the calculated bubble departure diameter for a heavily aged surface of $2.6 \cdot 10^{-4} \mathrm{~m}$, the density of nucleation sites of $1.5 \cdot 10^{7} \mathrm{~m}^{-2}$ is calculated with Eq. (5). For a fresh heater, a contact angle of $40 \mathrm{deg}$, [7] could be assumed, and the predictions of Eq. (4) and (5) are $D_{b}=2.08 \cdot 10^{-3} \mathrm{~m}$ and $n=2.3 \cdot 10^{5}$ sites $/ \mathrm{m}^{2}$. According to the representation of nucleation sites with the zones shown in Figure 1 and the condition of the complete heating surface covering with bubbles, the width of the zone should be equal to the bubble departure diameter. The width of the zone in the millimeter range, which is shown to be appropriate for fresh heaters, can be resolved within the numerical mesh with the acceptable number of control volumes.

The second parameter that determines the pool boiling dynamics is the bubble residence time on the heating surface. This is the time of the bubble growth up to the bubble departure diameter. It can be predicted from the relation between the bubble diameter and the bubble growth time [13]
$D_{b}=2\left(\gamma J a+\sqrt{\gamma^{2} J a^{2}+2 \beta J a}\right) \sqrt{a \tau}$

where $\mathrm{Ja}$ is the Jacob number

$J a=\frac{c_{p} \Delta T}{h_{12}} \frac{\rho_{1}}{\rho_{2}}$

By substituting Eq. (4) which determines the separation bubble diameter into Eq. (5), the bubble residence time on the heating surface is derived in the following form

$$
\tau=\frac{(0.0208 \times \theta)^{2} L_{c}^{2}}{4 a\left(\gamma J a+\sqrt{\gamma^{2}+J a^{2}+2 \beta J a}\right)}
$$

as the function of the wetting contact angle $\theta$ and the Jacob number.

\section{Governing Equations}

Three-dimensional liquid and vapor two-phase flow is modelled by the two-fluid model $[14,15]$. Mass, momentum and the energy fluid flow conservation equations are written for both phases, while the interface transfer processes are modeled by"closure laws". This approach implies non-equilibrium thermal and flow conditions.

The two-phase flow is observed as semi-compressible, that is, the acoustic flow effects are neglected, while the influence of the pressure change on the vapor and liquid thermo-physical properties is taken into account. The surface tension is neglected, as it is not imporant for the bulk two-phase flow phenomena. Hence, the pressure is the same for both phases within the numerical control volume. Conservation equations take the following form in the indicial notation.

Mass conservation equation

$\frac{\partial \alpha_{k} \rho_{k}}{\partial t}+\frac{\partial\left(\alpha_{k} \rho_{k} u_{k, i}\right)}{\partial x_{i}}=(-1)^{k}\left(\Gamma_{e}-\Gamma_{c}\right)$

Momentum conservation equation

$\frac{\partial\left(\alpha_{k} \rho_{k} u_{k, i}\right)}{\partial t}+\frac{\partial\left(\alpha_{k} \rho_{k} u_{k, i} u_{k, j}\right)}{\partial x_{i}}=-\alpha_{k} \frac{\partial p}{\partial x_{i}}+\frac{\partial}{\partial x_{j}}\left(\alpha_{k} \rho_{k} v_{k} \frac{\partial u_{k, i}}{\partial x_{j}}\right) \alpha_{k} \rho_{k} g_{i}+$ $(-1)^{k}\left(\Gamma_{e}-\Gamma_{c}\right) u_{i k, i}+(-1)^{k+1} F_{21, i}$

Energy conservation equation

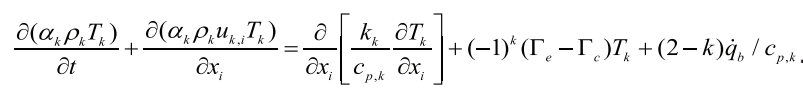

where $k=1$ for liquid and $k=2$ for vapor. The source terms for mass, momentum and thermal energy conservation are written on the r.h.s. of Eq. (8)-(10). The intensity of the phase transition, which is the mass of evaporation or condensation per unit volume and time, are denoted with $\Gamma_{e}$ and $\Gamma_{c}$ respectively. The force of vapor and liquid interfacial drag per unit volume in $i$ Cartesian 
direction is denoted with $F_{2 l, i}$. The term $q$ represents a volumetric heat rate from the wall to the corresponding fluid phase per unit volume.

To above system of equations, the volume fraction balance is added as follows

$$
\alpha_{1}+\alpha_{2}=1
$$

Energy equation for the heated wall

$$
\frac{\partial T}{\partial t}=a \nabla^{2} T+\frac{\dot{q}_{h}}{\left(\rho c_{p}\right)_{p}}-\frac{\dot{q}_{b}}{\left(\rho c_{p}\right)_{p}}
$$

where $q_{h}$ is the volumetric heat source in the wall, while $q_{b}$ is the heat sink in the control volumes on the wall surface due to the bubble growth, and the heat source in the fluid control volumes on the wall when the bubble growth occurs. It is assumed that the bubble nucleation does not occur i.e. the heat source $q_{b}$ equals zero, if the void fraction in the control volume on the wall surface is higher than $1 \cdot 10^{-5}$.

\section{Closure Laws}

The calculation of the interfacial drag force $\left(\vec{F}_{21}\right)$ is a crucial step for the proper prediction of the relative velocities between the vapor and liquid phase, and consequently the void fraction. The interfacial drag force per unit volume of computational cell is calculated as in [15]

$$
F_{21, i}=\frac{3}{4} \alpha_{2} \rho_{1} \frac{C_{D}}{D_{P}} \sqrt{\sum_{j=1}^{3}\left(u_{2, j}-u_{1, j}\right)^{2}}\left(u_{2, i}-u_{1, i}\right)
$$

where $C_{D}$ is the interfacial drag coefficient, and $D_{P}$ is the diameter of the dispersed particle. The correlation for the interfacial drag coefficient $C_{D}$ is proposed in the following form

$$
C_{D}=1.487 D_{P}\left(\frac{g \Delta \rho}{\sigma}\right)^{1 / 2}\left(1-\alpha_{2}\right)^{3}\left(1-0.75 \alpha_{2}\right)^{2}
$$

where the dependence on the mixture void fraction $\alpha$, has the same function form as the CATHARE code correlation [16] for the interface friction in the transitional two-phase flow patterns. The lift force acts in the direction perpendicular to the relative velocity,

$$
F_{L 2, i}=C_{L} \rho_{1} \alpha_{2}\left[\begin{array}{c}
\left(u_{2, j}-u_{1, j}\right) \frac{\partial u_{1, j}}{\partial x_{i}} \\
-\left(u_{2, j}-u_{1, j}\right) \frac{\partial u_{1, j}}{\partial x_{j}}
\end{array}\right] .
$$

Here, the adopted value for $C_{L}=0,3$ is similar to the one used for dispersed bubbly flow.

The intensity of evaporation and the condensation rate in the two-phase mixture is calculated with the simple empirical model that takes into account the phase change relaxation time $-\tau$.

$$
\Gamma_{e}=k_{e} \alpha_{1}\left(T_{1}-T_{2}^{\prime \prime}\right)=\frac{\alpha_{1} \rho_{1}}{\tau_{e}}\left(T_{1}-T_{2}^{\prime \prime}\right)
$$

$$
\Gamma_{c}=k_{c} \alpha_{1}\left(T_{2}^{\prime \prime}-T_{1}\right)=\frac{\alpha_{1} \rho_{1}}{\tau_{c}}\left(T_{2}^{\prime \prime}-T_{1}\right)
$$

\section{Numerical Method}

The control volume based finite difference method is applied for the numerical solution of the set of balance Equations (8)-(10). A pressure-correction equation is derived according to the SIMPLE numerical method [17] from the momentum and mass balance equations. A three-dimensional flow field is discretized in Cartesian coordinates. A numerical grid is made from $40 \times 50 \times 40$ control volumes. The numerical grid consists of two parts: the heated wall $(40 \times 10 \times 40$ control volumes $)$ and the two phase mixture $(40 \times 40 \times 40$ control volumes). The heated bottom wall is divided into four by four zones, where the locations of vapor generation in the control volumes at the surface of the heater are determined with different values of the random function for each zone.

A discretization of partial differential equations is carried out by their integration over control volumes of basic and staggered grids. The convection terms are approximated with upwind finite differences, while diffusion and source terms are approximated with central differences. Fully implicit time integration is applied. The resulting set of algebraic equations is solved iteratively with the lineby-line TDMA (Three-Diagonal-Matrix Algorithm). The calculation error for every balance equation and every control volume is kept within prescribed limits by the iterative solution of sets of linear algebraic equations. The criterion for the overall calculation procedure solution is the fulfilment of the mass balance for every control volume within the prescribed error. Also, this criterion implies that the overall mass balance for the whole flow field is achieved.

\section{Results of Three-Dimensional Numerical Simulation} and Discussions

Figure 3 shows a three-dimensional (3D) view at the void fraction distribution in pool boiling for two different values of the heat flux. The larger void lumps are formed in case of the higher heat flux. Consequently, the swell level position is higher in case of the higher heat flux. In case of $100 \mathrm{~kW} / \mathrm{m}^{2}$ heat flux, the swell level is almost plane, while in the case of $200 \mathrm{~kW} / \mathrm{m}^{2}$ a typical bursting of large vapour lumps is observed at the swell level. Also, the formation of vapour layers at certain parts of the bottom heating wall is observed. Figure 4 shows vapor blankets formation on the heater surface with the increase of the heat flux. In case of the lower heat flux, the vapor spots are formed at the nucleation sites while at the higher heat flux $\left(200 \mathrm{~kW} / \mathrm{m}^{2}\right)$, wider vapor blankets are formed due to intensive vapor generation at randomly chosen nucleation sites, as well as due to merging of several vapor lumps into a larger one. 

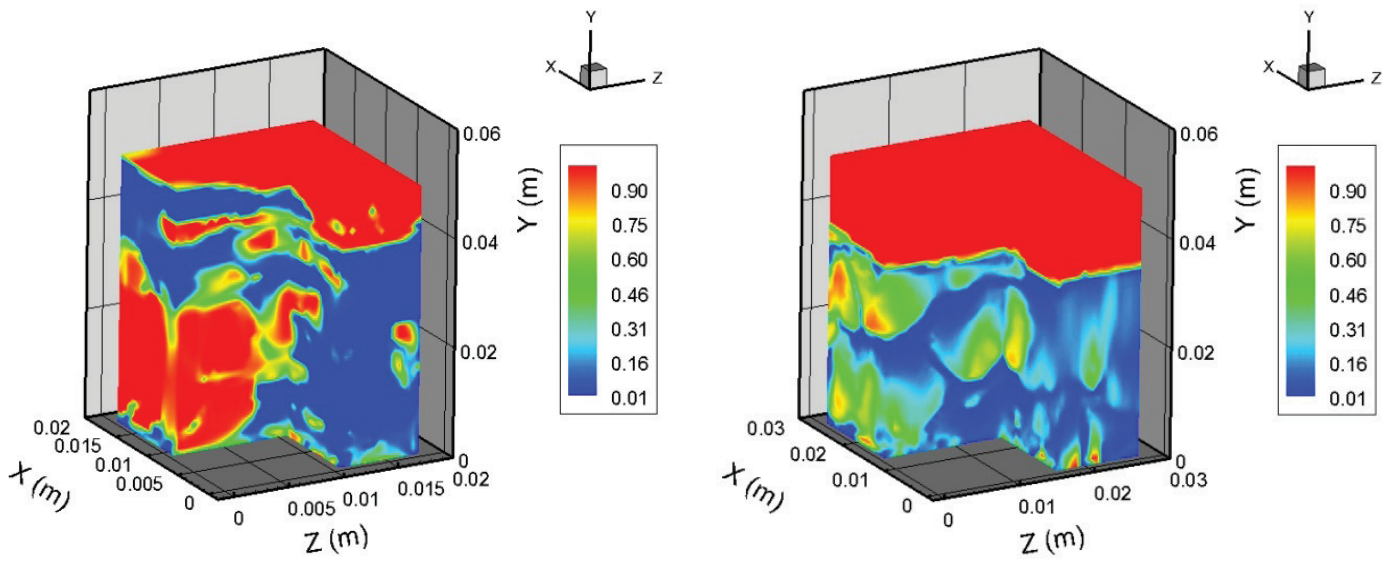

Figure 3. 3D view of void fractions at the pool boiling (heat flux $q=200 \mathrm{~kW} / \mathrm{m}^{2}-$ left, $q=100 \mathrm{~kW} / \mathrm{m}^{2}$-right)
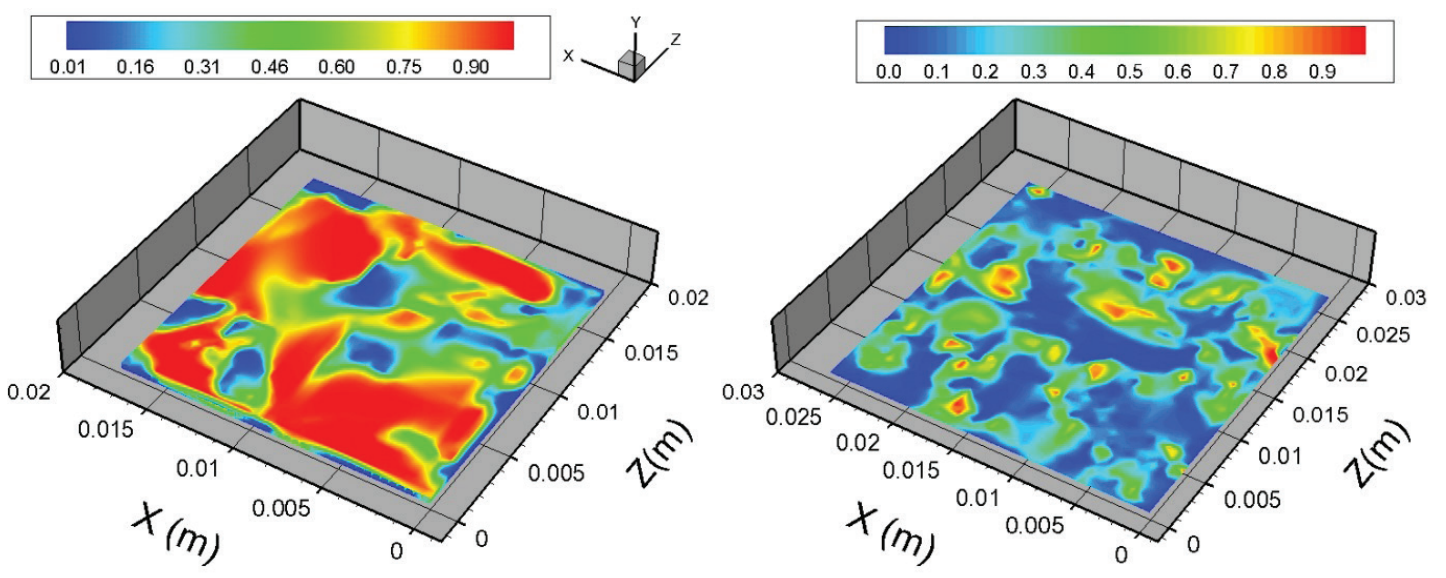

Figure 4. 2D planes of void fractions at nucleation sites at the heating wall ( $q=200 \mathrm{~kW} / \mathrm{m}^{2}$-left, $\mathrm{q}=100 \mathrm{~kW} / \mathrm{m}^{2}$-right $)$
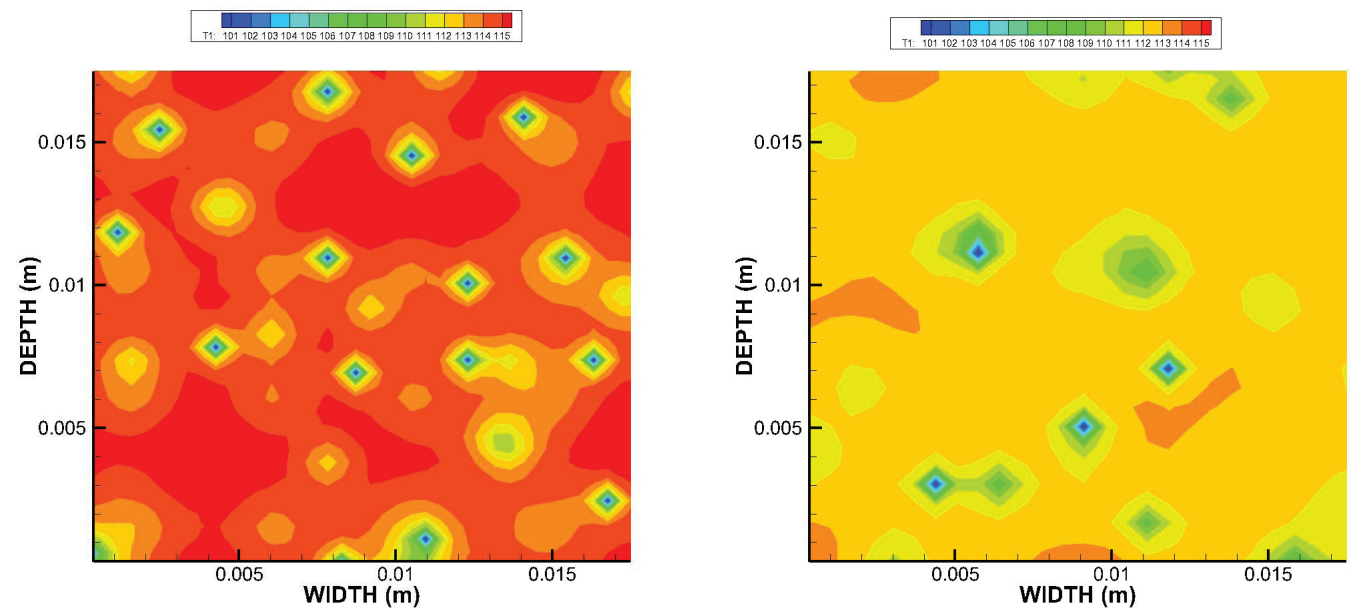

Figure 5. Temperature distribution on the horizontal heated surface $\left(q=200 \mathrm{~kW} / \mathrm{m}^{2}-\mathrm{left}\right.$, $\mathrm{q}=100 \mathrm{~kW} / \mathrm{m}^{2}$-right) 

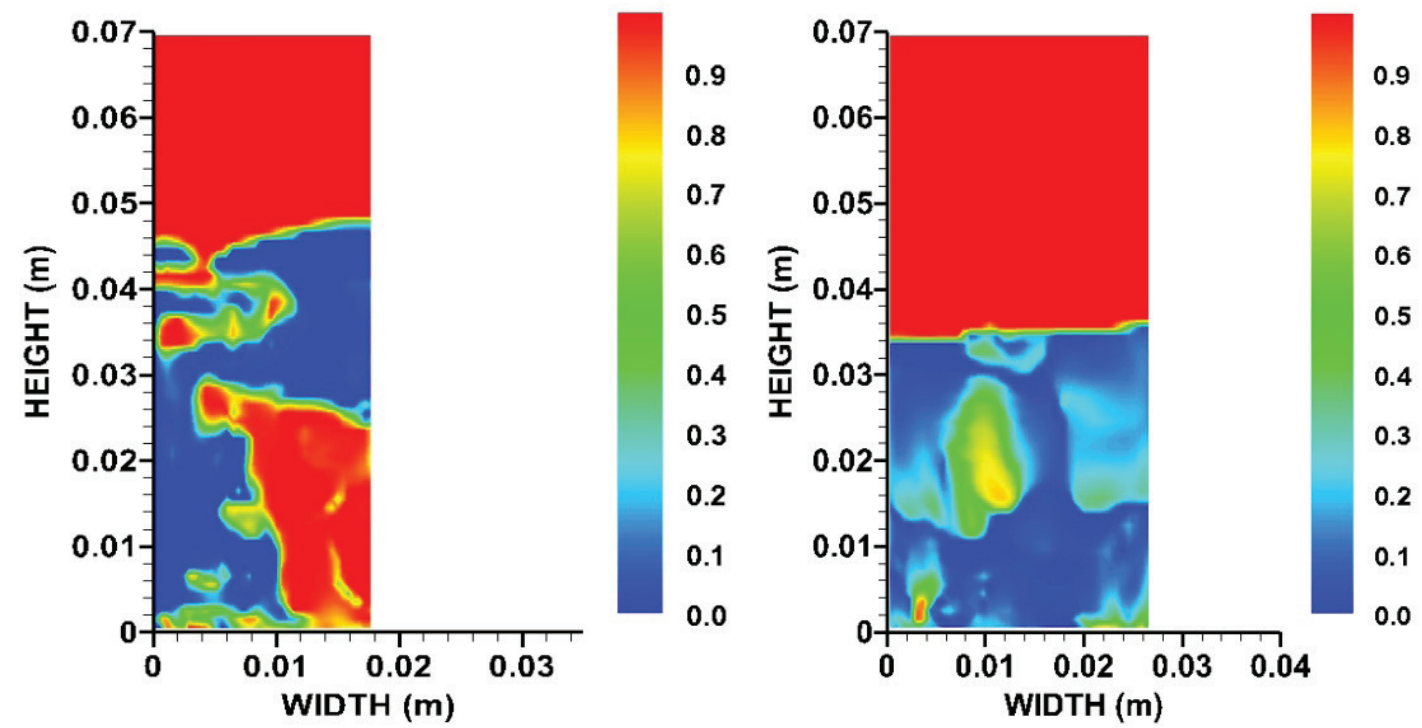

Figure 6. Void fraction distribution at heat fluxes of $q=200 \mathrm{~kW} / \mathrm{m}^{2}-\mathrm{left}, \mathrm{q}=100 \mathrm{~kW} / \mathrm{m}^{2}$-right

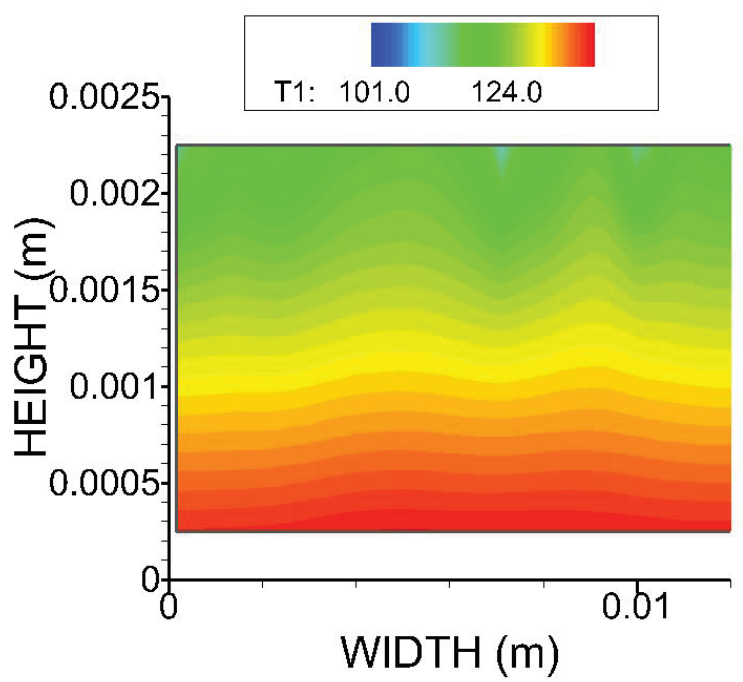

Figure 7. Temperature distribution through the wall

Nomenclature

thermal diffusivity, $\left[\mathrm{m}^{2} \mathrm{~s}^{-1}\right]$

width of the nucleation zone, $[\mathrm{m}]$

specific heat, $\left[\mathrm{Jkg}^{-1} \mathrm{~K}^{-1}\right]$

interfacial drag coefficient [-]

parameter [-]

diameter, [m]

bubble departure diameter, $[\mathrm{m}]$

force per unit volume, [ $\left.\mathrm{Nm}^{-3}\right]$

gravitational acceleration, $\left[\mathrm{ms}^{-2}\right]$

latent heat of evaporation $[\mathrm{J} / \mathrm{kg}]$

Jacobs number [-]

thermal conductivity, $\left[\mathrm{Wm}^{-1} \mathrm{~K}^{-1}\right]$

water capillary length, $[\mathrm{m}]$

density of nucleation sites, $\left[\mathrm{m}^{-2}\right]$

pressure, $[\mathrm{Pa}]$

heat flux, [ $\left.\mathrm{Wm}^{-2}\right]$

volumetric heat rate, $\left[\mathrm{Wm}^{-3}\right]$

volumetric heat source for bubble

generation on the heater's surface, $\left[\mathrm{Wm}^{-3}\right]$

time, [s]

temperature, $[\mathrm{K}]$

velocity, $[\mathrm{m} / \mathrm{s}]$

coordinate,[m]
Greek:

$\alpha$ void fraction [-]

empirical constant [-]

empirical constant [-]

phase transition rate, $\left[\mathrm{kgm}^{-3} \mathrm{~s}^{-1}\right]$

wetting contact angle, [deg]

density, $\left[\mathrm{kgm}^{-3}\right]$

kinematic viscosity $\left[\mathrm{m}^{2} \mathrm{~s}^{-1}\right]$

surface tension, $[\mathrm{N} / \mathrm{m}]$

phase change relaxation time, $[\mathrm{s}]$

Indexes:

b bubble

c condensation

evaporation

phase index $(k=1,2)$

particle

saturation

wall

water

steam

interfacial

saturated liquid

saturated vapour 
Figure 5 shows the temperature field at the heater surface. Higher temperatures and larger number of nucleation sites are observed for a higher heat flux value of $200 \mathrm{~kW} / \mathrm{m}^{2}$. Calculated two-phase mixture structures are shown in Figure 6 . The formation of the vapor blanket at the heating wall is observed, with vapor plums rising from the bottom. The temperature field in the heated wall is shown in Figure 7. The non-uniformity of the temperature field in horizontal planes is caused by the discrete locations of the bubble nucleation sites at the wall top surface.

The presented results are obtained with the numeri-

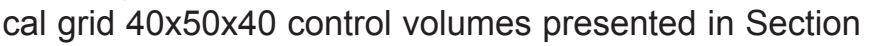
4.2. A grid refinement test was performed for the numerical experiment with the heat flux of $200 \mathrm{~kW} / \mathrm{m}^{2}$ with the numerical mesh with a doubled number of control volumes in all three dimensions $(80 \times 20 \times 80$ control volumes) for the heated wall and a doubled number of control volumes in horizontal directions and a tripled number

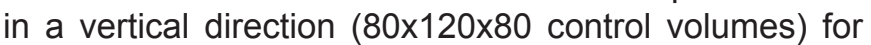
the water pool. The comparison between these two sets of results shows that the difference between mean temperatures of the heated wall top surface in simulations with the fine and coarser grid is less than $0.5 \mathrm{~K}$. In addition, there were no practical differences in the pool twophase mixture behaviour and the wall temperature field for these two cases.

\section{Conclusions}

Three-dimensional numerical investigation of pool boiling of saturated water under atmospheric conditions is presented for two values of the heat flux. The two-phase mixture flow in pool boiling is simulated with the developed two-fluid model and it is coupled with the solving of the transient heat conduction in the heated wall and heat convection on the heated surface. It is shown that the vapor blanket forms on the horizontal top surface of the heater in case of a higher heat flux value, which leads to the heated wall surface temperature rise.

Developed modelling and numerical methodology revealed that the combined application of the basic deterministic conservation laws for the continuous two-phase flow field and the stochastic characteristics of the vapor generation at the heated wall are able to simulate complex pool boiling conditions. In this way, already known and established physical laws, with the application of simple rules for vapor generation dynamics, can generate complex behaviors of boiling systems. The obtained results on the twophase mixture structure in pool boiling and the temperature field at the heater surface show that the applied algorithm for the prediction of heating wall boundary conditions takes into account the complex micro and nano-scale effects. As presented, the wall superheating above the boiling saturation temperature depends on the bubble nucleation density which is determined both by the heat flux and the aging of the heated wall surface. Therefore, the information about the status of the heated wall surface, whether it is aged or fresh surface, is input for the boiling prediction. Stable and efficient calculations for two different values of nucleation site density and bubble residence time demonstrate the robustness of the applied numerical approach. This numerical method could be applied to the investigation of the basic thermal-hydraulic mechanisms on the heater wall. It can enable the investigation of the influence of micro-scale parameters, such as density of nucleation sites and bubble residence time on the heating wall, on the dynamics of pool boiling.

\section{Acknowledgements}

This work has been supported by the Ministry of Education, Science and Technological Development of the Republic of Serbia (Project: „Increase in energy and ecology efficiency of processes in pulverized coal-fired furnace and optimization of utility steam boiler air preheater by using inhouse developed software tools", Project number TR-33018)

\section{References}

[1] B.J.Zhang, K.J.Kim, Nucleate pool boiling heat transfer augmentation on hydrophobic self-assembly mono-layered aluminia nano-porous surfaces, International Journal of Heat and Mass Transfer 73(2014) 551-561

[2] P.Xu, Q.Li, Y.Xuan, Enhanced boiling heat transfer on composite porous surface, International Journal of Heat and Mass Transfer 80 (2015) 107-114

[3] A. Sanna, C. Hutter, D. B. R. Kenning, T. G. Karayannis, K. Sefiane, R. A. Nelson, Numerical investigation of nucleate boiling heat transfer on thin substrates, International Journal of Heat and Mass Transfer, 76(2014) 45-64

[4] A. Stojanovic, V. Stevanović, D. Živković, S. Belošević, N. Crnomarković, B. Stanković, I. Tomanović, A. Milićević, Review of Heat Transfer Mechanisms in Pool Boiling, Proceedings of International Conference Power Plants, Zlatibor Serbia, Oct 28th-31st, 2014, ISBN 978-86-7877024-1,2014-165, pp. 729-743

[5] J. Kim, Review of nucleate pool boiling bubble heat transfer mechanisms, International Journal of Multiphase Flow, 35 (2009) 1067-1076

[6] Theofanus, T. G. Addressing the Complexity of Multiphase Flows, Proceedings, 39th European Two-Phase Flow Group Meeting, Aveiro, Portugal, June 17-21, 2001.

[7] Theofanus, T.G., Tu, J. P., Dinh, T. N., Salmassi, T., Dinh, A. T., Gasljevic, K., Li, G. J., The Physics of Boiling at Burnout, Proceedings, 4th International Conference on Multiphase Flow, New Orleans, Lousiana, USA, May 27-June 1, 2001

[8] Theofanus, T. G., Tu, J. P., Dinh, A. T., Dinh, T. N., The Boiling Crises Phenomenon, Experimental Thermal and Fluid Science, 2002

[9] M. Pezo, V. Stevanovic, Numerical Prediction of Critical Heat Flux in Pool Boiling with the Two-fluid Model, International Journal of Heat and Mass Transfer 54 (2011) 3296-3303

[10] M. Pezo, V. Stevanovic, Numerical Prediction of Nucleate Boiling Heat Transfer Coefficient under High Heat Fluxes, Thermal Science, Article in Press

[11] Sakashita H., Kumada T., Method for Predicting Curves of Saturated Nucleate Boiling, Int Journal of Heat and Mass Transfer Vol. 44, pp 673-682, 2001 
[12] Zeng, L. Z., Klausner, J. F., Mei, R., A Unified Model for the Prediction of Bubble Detechment Diameters in Boiling Systems - I. Pool Boiling, International Journal of Heat and Mass Transfer Vol. 36, pp. 2261-2270, 1993.

[13] Sakashita H., Kumada T., Method for Predicting Curves of Saturated Nucleate Boiling, Int Journal of Heat and Mass Transfer Vol. 44, pp 673-682, 2001.

[14] Isachenko, V P., Osipova, V. A., Sukomel, A.S., Heat Transfer, Mir Publisher Moscow, pp. 311-312, 317, 1980

[15] Stosic Z, Stevanovic V., Numerical Approach to the Simulation of One-phase and Two-phase Reactor Coolant Flow around Nuclear Fuel Spacers, International Conference on Nuclear Engineering - ICONE 9, Nice, April 8-12, 2001.
[16] Ishii, M., Two-fluid Model for Two-phase Flow, 2nd Int Workshop on Two-Phase Flow Fundamentals, Rensselaer Polytechnic Institute, USA, 1987.

[17] Rousseau J. C., Houdayer G., Advanced Safety Code CATHARE Summary of Verification Studies on Separate Effects Experiments, Proc. NURETEH-2, 1983

[18] Patankar, S., Numerical Heat Transfer and Fluid Flow, Hemisphere Publ. Co., 1980

Izvod

\section{NUMERIČKO PROUČAVANJE PROCESA RAZMENE TOPLOTE PRI KLJUČANJU U VELIKOJ ZAPREMINI}

Andrijana Stojanović ${ }^{1}$, Vladimir Stevanović ${ }^{2}$, Milan Petrović ${ }^{2}$, Dragoljub Živković ${ }^{3}$, Branislav Stanković ${ }^{1}$

\footnotetext{
1 Univerzitet u Beogradu, Institut za nuklearne nauke Vinča, Laboratorija za termotehniku i energetiku, Beograd, Srbija

2 Mašinski fakultet, Univerzitet u Beogradu, Beograd, Srbija,

3 Mašinski fakultet, Univerzitet u Nišu, Niš, Srbija
}

U ovom radu je izvršena trodimenzionalna numerička simulacija atmosferskog, zasićenog ključanja u velikoj zapremini. Primenjeni matematički model i numerička metoda omogućavaju potpuni prikaz ponašanja dvofazne mešavine na grejnoj površini kao i predviđanje slobodnog nivoa tečnosti. Ovde prikazano trodimenzionalno istraživanje je sprovedeno kako bi se uzela u obzir konvektivna razmena toplote na grejnoj površini kao i prostorni efekti generacije pare i dvofaznog toka, kao što su disprzija faza u dvofaznoj mešavini. Predstavljeni su rezultati simulacije nakon kratkog vremenskog perioda od početka zagrevanja i formiranja mehurova na grejnoj površini. Prikazani su popunjenost grejne površine vodom i parcijalna okvašenost površine za niže vrednosti toplotnog fluksa. Diskutovan je uticaj gustine nukleacije i vremena zadržavanja mehurova na grejnom zidu na dinamiku ključanja. Takođe je proučen uticaj intenziteta toplotnog fluksa na dinamiku ključanja u velikoj zapremini. Primenjeni numerički metod i matematički model je pokazao ispravnost, omogućavajući stabilan proračun za širok opseg primenjenih parametara pri modeliranju.
(ORIGINALNI NAUČNI RAD)

UDK 66.046.7:532.5:519.6

Ključne reči: ključanje u velikoj zapremini, toplotni fluks, matematičko modeliranje 